\title{
ENTRE DIAGRAMAS E PROCESSOS - NOTAS SOBRE DISCURSOS, ENUNCIADOS E PRÁTICAS CONTEMPORÂNEAS
}

\section{BETWEEN DIAGRAMS AND PROCESSES: SPEECHES, THEORIES AND CONTEMPORARYPRACTICES ANNOTATTONS}

\author{
SILVA, ARIADNE MORAES \\ Doutora, professora da Faculdade de Arquitetura da UFBA, ariadnemoraes@gmail.com
}

\section{RESUMO}

Este trabalho faz parte de uma pesquisa de doutorado iniciada em 2011, com o propósito de inserir a discussão do diagrama enquanto dispositivo processual e virtual atualizado conceitualmente no campo da teoria e da crítica da arquitetura e do urbanismo, na interface da ciência, da arte e da filosofia. O diagrama não é tratado como uma ferramenta estática de representação, mas como uma máquina de forças que emerge como um instrumento incorporal e dinâmico de ação social, capaz de fomentar novos discursos, traduzir enunciados e problematizar a atual produção projetual. A partir da reconstituição do diagrama moderno, entre o abstracionismo e os procedimentos geométricos sistematizados por alguns arquitetos e pensadores nos últimos 40 anos, verifica-se a necessidade de constante atualização e ressignificação da própria função do papel do processo e da dimensão diagramática como rede aberta na contemporaneidade. Busca-se a ênfase na arquitetura como esquema, esboço, fluxos e experimentação, onde o modo de fazer torna-se tão emblemático quanto o produto final. E é nessa linha de fuga que 0 diagrama pode se transformar em uma máquina de resistência criativa frente aos modelos hegemônicos, incorporando novos saberes e práticas éticas, estéticas e políticas.

PALAVRAS-CHAVE: diagramas; processos; teoria e crítica; arquitetura contemporânea.

\section{ABSTRACT}

This research aims to depict the subject of the diagram, as a processual and virtual device, updated in the sector of the theory and analysis of Architecture and Urbanism. From an inherent conceptual perspective, this study proposes dialogues between the formal logic - the power relations of an incorporeal and virtual diagram and its possible effects on Science, Art and Philosophy interface. The Diagram here, is not portrayed as a static representational device. Instead, it presents itself as a constant ever evolving working machine support, always questioning the contemporary Architecture production. The main purpose of this essay is to provide the Architecture with power, in order to understand it as a strategy, a process, a starter rather than a final product. Features, sketches, lines, strokes - the discovery of procedures through diagrams has become a wide and open net, made of subjects and functions in constant mutation. The Diagrammatic role is projective, hence it opens new territories and opportunities to practice, capable of building a powerful creative resistance against the current hegemonic and consensual status quo. The diagram can be a powerful ethical, aesthetic and political practices.

KEYWORDS: diagrams; processes; theory and criticism; contemporary architecture. 


\section{INTRODUÇÃO}

É bem verdade que o diagrama não é um assunto novo na história da arquitetura. Compreendido enquanto um território expandido atravessado por uma série de dispositivos processuais, o diagrama tem assumido uma posição relevante nos principais debates contemporâneos que articulam experiência, ação e teoria no campo da prática arquitetônica. Ironicamente complexo e potencialmente conceitual, o diagrama é capaz de agenciar (afetar) pintores, arquitetos, cartógrafos, geógrafos, filósofos e escritores ${ }^{1}$.

É sempre um risco falar de algo que está em processo, ainda mais quando a sobreposição de mapas nem sempre estabelece territórios comuns, possíveis de serem transitados. Como destaca Anthony Vidler (2010), a palavra diagrama se tornou uma espécie de "varinha mágica", a "dança do momento", ou seja, quase todo arquiteto contemporâneo de "respeito", que transita nos mais altos circuitos das produções dessa esfera, está fazendo "arquitetura-diagrama".

Os espaços arquitetônicos são, por definição, uma parte do sistema social. Cada sociedade ao seu tempo tem os seus diagramas, as suas relações, os seus requisitos e as suas necessidades. O diagrama é uma espécie de máquina abstrata, conforme conceituado por Gilles Deleuze e Félix Guattari (1995; 1997b), mas também um dispositivo de poder, de acordo com Michel Foucault (1975), na qual os saberes são postos a funcionar. Ele emerge como uma ferramenta de produção de arquiteturas ou de produção de discursos e enunciados, estendida às esferas artísticas e sociais. Forma e palavra, espaço e linguagem, o diagrama é mais performático que representacional - um motor capaz de diagramatizar e traçar planos.

Figura 1: Diagrama de Foucault.

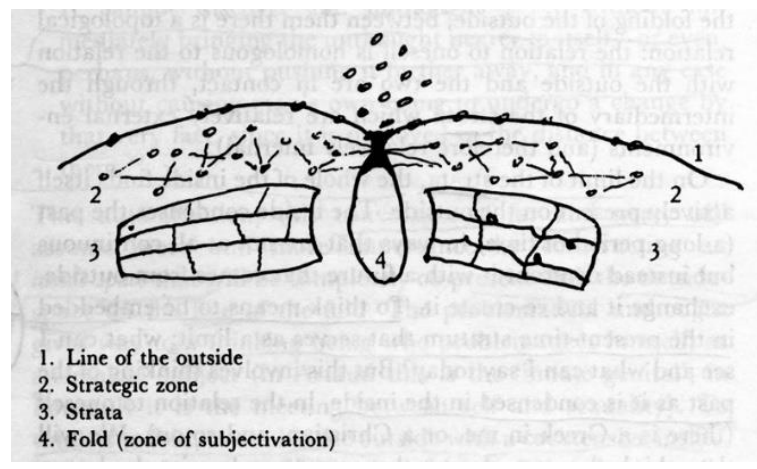

Fonte: Deleuze (2005).

A partir da segunda metade da década de 1990, um arsenal de publicações abordando aproximações com esse tema foi difundido na interface da arquitetura. Duarte (idem) chegou a afirmar que o uso do diagrama assumiu um papel protagonista no cenário da representação e da geração do conhecimento arquitetônico, superando, inclusive, o que ele chama de desenho tradicional. Esse panorama de "eXcesso" e de mares turbulentos, Rovenir Duarte denominou "diagrammania", ao fazer referência ao título da edição n.74 da revista alemã de cultura urbana e arquitetônica - Daidalos (1999).

Figura 2: A febre do diagrama. Horizonte excessivo? Publicações entre 1996 e 2013.

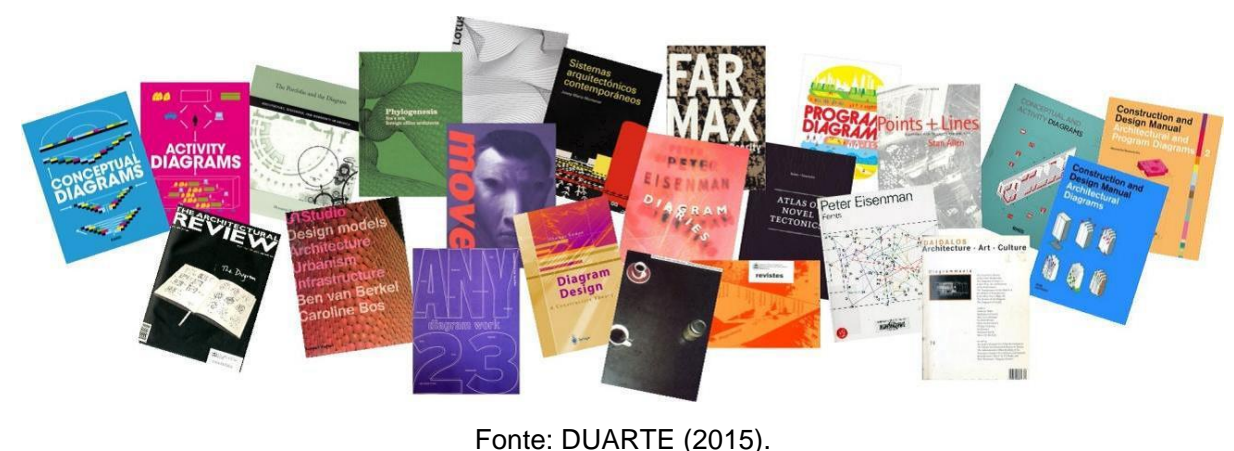

Foi exatamente em 1996 que o arquiteto Toyo Ito introduziu enfaticamente o termo diagrama ao discutir a produção de outra arquiteta asiática - Kazuyo Sejima (El Croquis, 1996)². Fazer arquitetura-diagrama, então, se tornou uma febre e passou a infestar os principais mananciais editorias e periódicos de arquitetura e urbanismo ${ }^{3}$.

No meio desses arquivos, entretanto, aparentemente diferentes na superfície e calorosamente debatidos entre seus protagonistas, resultou em um dispositivo que, em divergentes modos e aproximações, foi 
chamado de "diagrama". Surgiu, com intensidade, um campo ampliado e vigente de ação para a arquitetura: novos modos de trabalhar, variação de experimentações geométricas, tentativas de ultrapassar os conceitos binários herdados do modernismo, deslocamentos do binômio forma versus função para uma matriz de informação - uma multiplicidade de ensaios de enquadramento.

$\mathrm{Na}$ arquitetura, a descoberta da processualidade através de diagramas se transformou em uma rede aberta e de confronto de alguns arquitetos pós-modernos e contemporâneos. Imersos em dispositivos de informação, meios digitais e comunicação quase que instantânea, a dimensão diagramática que constrói espaços em suspensão, praticamente se multiplica. Não interessa apenas o espaço construído, mas o que escapa, o que informa e transforma a matéria.

Figura 3: Publicações que abordam o diagrama na interface da arquitetura. Na rota da diagrammania.

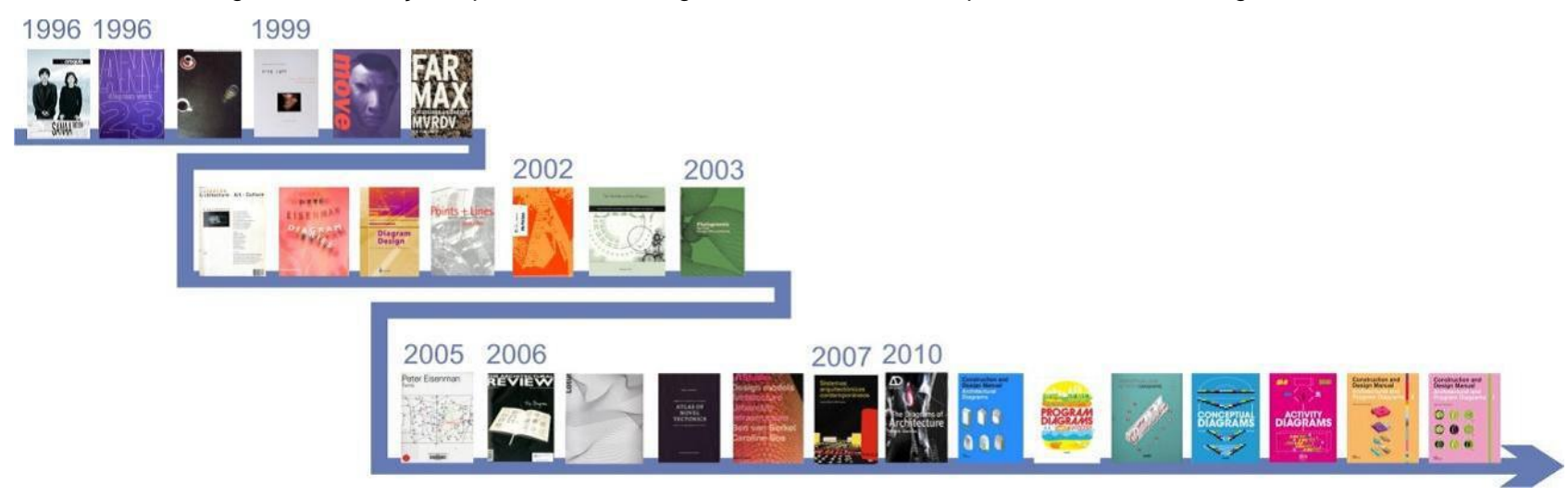

Fonte: DUARTE (2015).

\section{A RECONSTITUIÇÃO DO DIAGRAMA MODERNO NA CONTEMPORANEIDADE}

Nesse meio tempo, Peter Eisenman $(2001)^{4}$, ao publicar Diagram Diaries, praticamente buscou comprovar que ele foi o arquiteto que, não só havia trabalhado a atualização do conceito do diagrama na produção de seus processos inventivos, antes do que qualquer outro arquiteto de sua geração, como atestou a utilização desse tipo de dispositivo em toda a sua carreira (VIDLER, 2010). Além disso, ele reexaminou suas principais obras e projetos, sendo o primeiro produtor do star system a atualizar os conceitos deleuzianos no campo da teoria e da crítica arquitetônica.

Refletindo sobre o uso do diagrama nas criações de suas arquiteturas, defendeu a intensidade da conexão do procedimento diagramático, não apenas enquanto processo projetual, mas enquanto um conceito incorporal, uma máquina de forças, muito próximo ao pensamento traçado por Gilles Deleuze ao explorar as pinturas do pintor irlandês Francis Bacon ${ }^{5}$. Eisenman estava influenciado, na época, por uma filosofia da diferença, e se abrigou de formulações estruturadas por pensadores como Michel Foucault e Jacques Derrida. Ao refletir sobre as críticas acerca do mundo da representação, se apropriou de ideias que atravessavam a filosofia da desconstrução e a potência da interface diagramática.

Figura 4: Arte digital sobre obra de Francis Bacon. The Virtual House (1997), Berlim - Eisenman Architects.
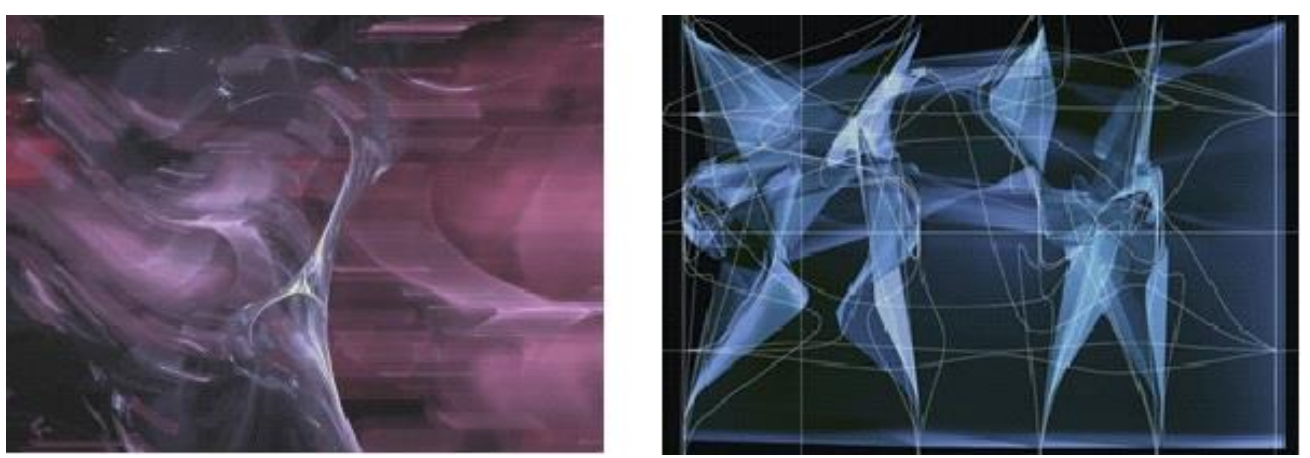

Fonte: www.enchgallery.com / Tracing Eisenman (2007).

Eisenman fez uma série de publicações posteriores, catálogos que expõem os seus processos: CODEX (2005a), Contropiede (2005b), Tracing Eisenman (2007), entre outros. A matriz cúbica foi trabalhada de forma sistemática enquanto diagrama na produção de uma série de casas projetadas por um intervalo de 
quase três décadas. Essa experimentação se iniciou ainda no final dos anos de 1960, logo após a apresentação de sua tese de doutoramento, intitulada The Formal Basis of Modern Architecture, ao revisitar a obra de Giuseppe Terragni (1904-1943), o edifício sede do partido fascista na cidade de Como (Itália), a Casa Del Fascio (1932-1936).

Ao percorrer as obras do arquiteto italiano Giuseppe Terragni ${ }^{6}$, Eisenman desmantelou o objeto clássico modernista e investigou as aparentes limitações da linguagem da arquitetura até a sua exaustão. A multiplicidade do sistema espacial manifestado por dispositivos tridimensionais dinâmicos (maquetes, esqueletos, perspectivas explodidas, planitas) ${ }^{7}$ é potencializada pelo desenvolvimento de uma geometria espaço-temporal que se constrói na quinta dimensão, ou seja, na própria manipulação direta do objeto - a poiética $^{8}$ do espaço. Esse tipo de procedimento, inclusive, já foi otimizado com o advento das ferramentas de modelação digitais, dispositivos que vão além da metafísica do diagrama em seus aspectos formais, remetendo-o às ações inorgânicas e contemporâneas apoiadas pela tecnologia.

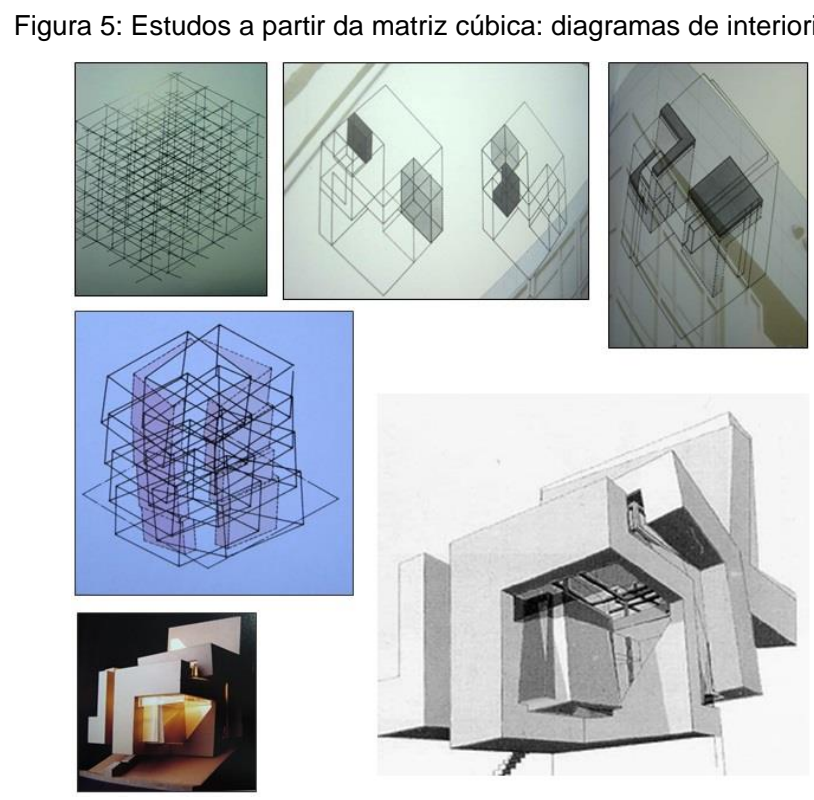

Fonte: EISENMAN $(2001 ; 2005 b)$

Sobre esse procedimento, Somol (2001, p.14) afirma que, nas séries das casas, Eisenman reconstitui o diagrama moderno, e elucida:

\begin{abstract}
Os diagramas transformacionais, numerados serialmente, das Casas I e II, assim como os diagramas retrospectivos criados para a obra de Terragni, sugerem que as estruturas "finais" construídas são apenas signos indiciais que apontam para um processo mais amplo, do qual são apenas uma parte. Não se trata apenas de movimento gerado através de séries de contextos individuais - o processo todo mais se parece com uma operação cinemática, com sua montagem de quadros congelados (stills) - mas, dada a natureza da projeção axonométrica (exagerada aqui por sua construção transparente, em wireframe), há também uma oscilação constante e um movimento reversível contido em cada diagrama: o observador está ora dentro, ora fora; agora debaixo, agora sobre.
\end{abstract}

O tipo arquitetônico remete ao esquema desenvolvido por Andrea Palladio (1508-1580) para o Palazzo Thiene, em Vicenza (1542-1558) - uma tipologia de pátio central. O cubo, trabalhado por Eisenman, passa por uma série de questionamentos em sua estrutura formal bruta; esse elemento sofre distorções, extrusões, subtrações, decomposições e deslocalizações (SILVA, 2010).

O que Eisenman fez, ao experimentar composições diagramáticas enquanto eixos de desconstrução em edificações relativamente pequenas (habitações uni-domiciliares), foi enfatizar o processo de criação em detrimento do objeto acabado. A relevância de suas pesquisas aponta para a própria função do papel do processo, onde o modo de fazer converte-se em algo mais emblemático que o próprio artefato.

O arquiteto consegue dominar melhor essas pequenas escalas potencializando a sua própria relação subjetiva com o que está fazendo - se colocando entre e dentro dessas conexões interiores. A partir de então, Eisenman parte para investigação de diagramas mais conceituais e amplos no sentido de trabalhálos tanto na escala da cidade quanto na maturação de projetos maiores e coletivos (SILVA, 2015). 
A complexidade dessas conexões de saberes geométricos torna-se um desafio do ponto de vista operacional e das forças físicas, uma vez que nos coloca em uma posição quase que exaustiva de revisão perpétua de tais processos em operações transversais, perceptivas, rotacionais, decompositivas, disjuntivas, deslocadas, superexpostas e mutantes. Segundo Somol (2001, p.12) é o catálogo desses procedimentos que transforma a matéria da própria arquitetura, uma pré-condição disciplinar para uma abordagem diagramática.

Nesse processo de interação maquínica, Eisenman conseguiu trazer à tona a estética do grotesco e provocar estranhamento. Ele foi revolucionário, naquela fase, enquanto experiência de experimentação, mas não transgressor, pois seu aparente escape ainda se encontrava submetido às coordenadas geométricas, políticas, sociais, corporativas e especulativas - lócus da cultura hegemônica e régia.

Figura 6: Diagramas, croquis e modelos axonométricos
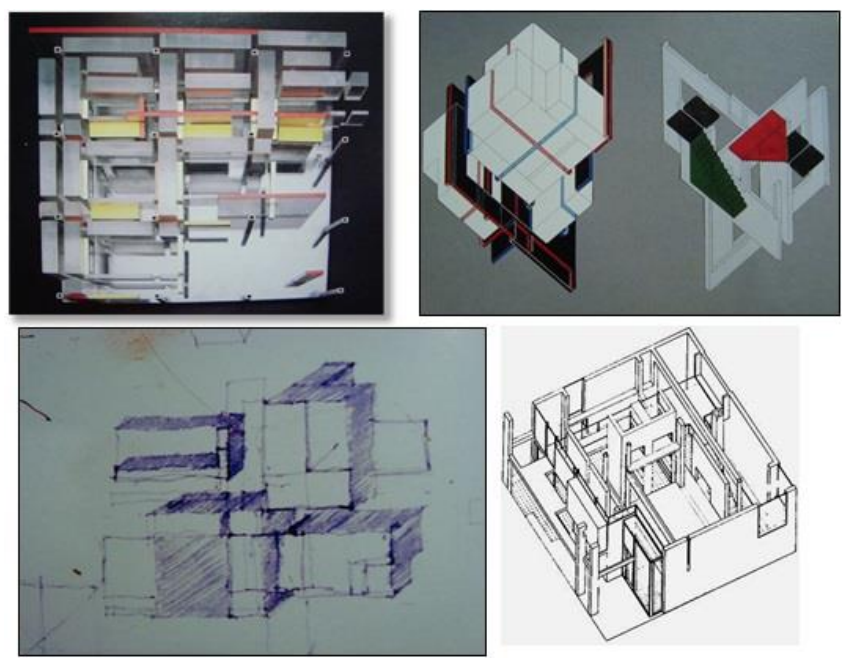

Fonte: Eisenman (2001)

Paradoxalmente, Eisenman é um dos poucos arquitetos que conseguiu revelar, naquele período pósmoderno, tais provocações (e uma certa crise do pensamento predominante) no rebatimento dos processos de suas arquiteturas, se re-singularizando ao trazer para suas formulações um discurso crítico e prospectivo sobre as artes. Além de expor o seu modus operandi e abrir a suposta caixa preta, a materialização de suas intenções de projeto se confunde com o próprio processo gerador, a partir da ênfase no modo de fazer, na penetração do espaço de transição e do intermezzo, que se apresenta antes do objeto pronto. $O$ uso do desenho axonométrico, herdado das vanguardas históricas do início do século $\mathrm{XX}$, em contraposição ao desenho clássico renascentista e que privilegiava a busca de semelhanças, talvez tenha sido sua maior contribuição.

Muitos trabalhos acadêmicos citam o arquiteto Peter Eisenman como referência fundamental para discutir articulações diagramáticas no universo da arquitetura e, de fato, ele forneceu um arcabouço importante ao suspender a análise formal de base estruturalista e dar ênfase à linguagem. Sobre esse aspecto, Deleuze $(1975)^{9}$ nos lembra que um sistema de linguagem é um sistema de ordem e não de informação, portanto aproxima-se de uma máquina de forças, mas uma força à mercê de um sistema de comando. Em uma escola, por exemplo, há o direcionamento para que o corpo docente e discente reproduzam enunciados conforme os postulados dominantes. Não é uma comunicação de informações, mas uma transmissão de ordens. A linguagem compreende a sintaxe, enquanto é elemento e componente do poder ${ }^{10}$. "Informar", nesses termos, é embutir um sistema de ordens precedente. Ordem, nesse sentido, não se configura como um sistema de organização ou "ordenamento", mas de comando, típico de instituições disciplinares em que prevalece a obediência como normatização.

Ilustra-se aqui um procedimento, entre tantos outros, em que a materialidade, a forma e o sistema de linguagem foram trabalhados em períodos diferentes e em escalas variáveis. Porém, nesse jogo em que a arquitetura faz surgir visibilidades, compreende-se que o rompimento com o mundo objetivável da representação é parcial. Implica, inclusive, em uma orientação particular que dispara igualmente um projeto social e disciplinar, não como a representação de uma condição particular, mas pela subversão de oposições e hierarquias normalmente constitutivas de um discurso (SOMOL, 2001).

A arquitetura continua dobrando (no consumo, no espetáculo e na sofisticação) e variando (na forma e nos usos). É uma potência de interioridade que, quando lançada para a exterioridade, vira espetáculo. Ou seja, há mudanças de grau e de nível, mas não transmutação de natureza! Nesse sentido, a produção 
diagramática encontra-se submetida a sistemas de regulação e sua potência aprisionada em paradigmas conservadores, quando não, capturados.

\section{Abstracionismo, procedimento geométrico ou ambiguidade estética?}

O diagrama sempre se fez presente no panorama histórico do pensamento e da representação da arquitetura; no entanto, deslocou-se de uma base que compreendia um tipo ou um paradigma, para uma operação processual que envolve repetição, acontecimento e diferença. Se em um dado período o diagrama esteve aprisionado em sua condição de aparato estático, o desvio emergente evoca sua condição performática e cinemática. Segundo Sperling (2008a, p.2):

(...) na arquitetura, antes mesmo da introdução das interfaces digitais de modelação e animação, diagrama e evento passaram a se encontrar, então, em um campo conceitualoperativo caracterizado pelo que se pode denominar de 'potência de processo'.

Essa potência do processo, ao qual se refere o professor do Instituto de Arquitetura e Urbanismo da USP, David Sperling, introduz duas questões fundamentais: uma efervescência do debate acerca de um amplo campo da arquitetura que precisa ser atualizado e desconstruído, mas, sobretudo de uma situação de crítica à própria disciplina.

Anthony Vidler (2010) reconhece a existência de um dualismo problemático que tem atormentado a arquitetura: forma e função, historicismo e abstração, utopia e realidade, estrutura e delimitação. Fundamentar uma nova experimentação formal, segundo ele, é uma tentativa capaz de reinterpretar as bases da disciplina e propor uma ampliação do seu próprio campo.

Embora, como ele mesmo sinaliza, novos princípios ${ }^{11}$ tenham surgido nesse pseudo-universo expandido, a dimensão da macropolítica ainda é muito presente (predominante, na verdade) nos projetos arquitetônicos e urbanísticos contemporâneos. O rompimento, quando acontece, é sempre relativo e ainda aprisionado na exploração da forma arquitetônica e seus sistemas de linguagem. O diagrama se situa dentro de uma visão limitada ao mundo da representação (espetacular) e inserido nos debates dominantes como mais um eixo ferramental incorporado à teoria e à história da arquitetura.

Em sua mais recente publicação, Josep Maria Montaner $(2017$, p.36) também chama a atenção acerca das limitações e riscos que o excesso de abstração vinculado ao diagrama pode conduzir a propostas desconectadas da realidade, nas quais predomine a autonomia e a arbitrariedade formal. Como consequência, pode-se implicar em uma retórica projetual que leve a uma arquitetura formalista.

Os diagramas (em suas exterioridades geométricas), muitas vezes, se confundiram com os desenhos arquitetônicos produzidos no período moderno e revelavam objetos que se inclinavam ao abstracionismo esboços, croquis e desenhos esquemáticos se transformaram diretamente em obra construída, sem passar pelas negociações peculiares do campo arquitetural.

Esse é um dos perigos miméticos na produção da arquitetura: quando a forma arquitetônica se torna a imagem construída do próprio diagrama. Nesse sentido, ele funciona como uma armadilha mecânica e se torna um dispositivo reducionista, sendo relegado à condição de mero abstracionismo geométrico.

Figura 7 Diagramas de organização de cluster: conexões e processamentos.

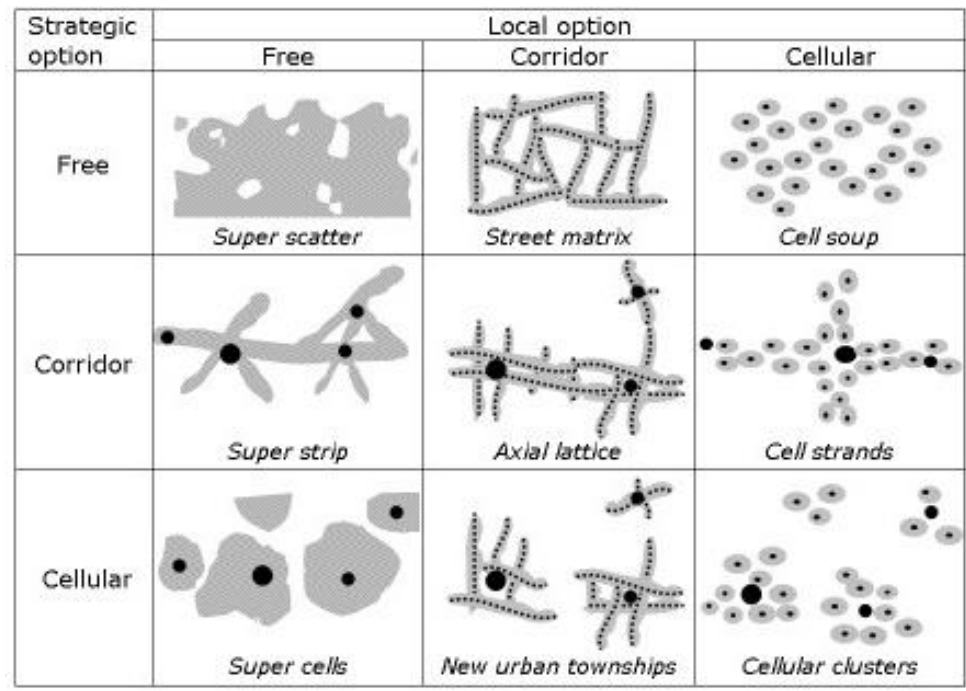

Fonte: Mark Garcia (2010). 
Anthony Vidler (2000) chama tais produtos de "abstrações de abstrações", ou seja, construções executadas e geradas a partir de diagramas analógicos dessa natureza. Ele demonstra as evocações esquemáticas e linhas rápidas de Le Corbusier ou as perspectivas de Mies Van der Rohe, traçadas velozmente a lápis, como exemplos de desenhos suspensos entre algum lugar (ou nenhum lugar) e um "design process" genérico.

Figura 8 "Diagram of lines and forms as they affect the physiology of sensations", de Le Corbusier.

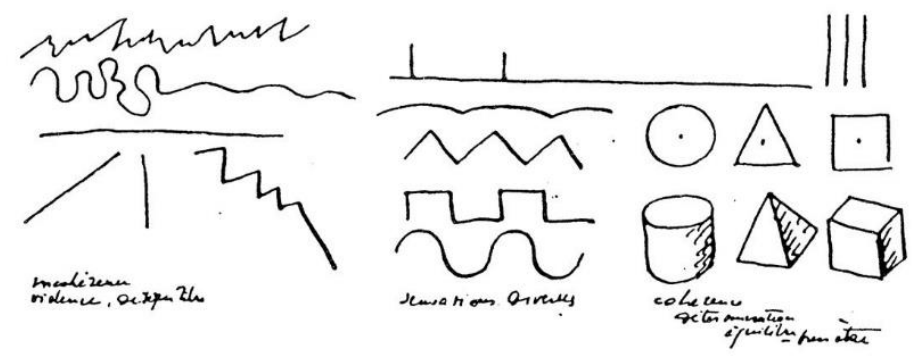

Fonte: Mark Garcia (2010).

Mas, será que os diagramas eram, de fato, abstratos, como colocados pela arquitetura moderna? Os diagramas de Le Corbusier eram intensos em sua interioridade, dentro de si mesmos eles eram potentes, pois traziam a força de um esboço explodido e aberto revelado por linhas traçadas com sutileza. Pode-se afirmar que todo desenho é uma obra de arte em potencial.

O desenho digital é o mapeamento de três ou quatro relações dimensionais em 2D (os planitas de Malevich) e, segundo Vidler (2000), é mais uma função da engenharia do que uma abstração. É nesse ponto que consiste a ambiguidade da estética da digitalização: estaríamos imersos em uma estética de dados, onde as informações são mapeadas à guisa de um funcionalismo esquemático herdado da modernidade? Entre diagramas modernos, ideologias historicistas, representações pós-modernistas e excessos digitais, o tempo da multiplicidade do sistema espacial parece não ter fim.

Embora a utilização de recursos computacionais nesse tipo de processo diagramático tenha imposto um outro ritmo e uma outra dimensão à produção de estruturas espaciais altamente sofisticadas, com perspectivas impressionantes, planos axonométricos e esquemas virtuais rebuscados, permitindo maior complexidade compositiva e plataformas de simultaneidade, onde processo e produto se confundem, formando uma nebulosa.

Figura 9 Formas extraídas de equações numéricas e modelos construídos a partir dos princípios da arquitetura líquida.
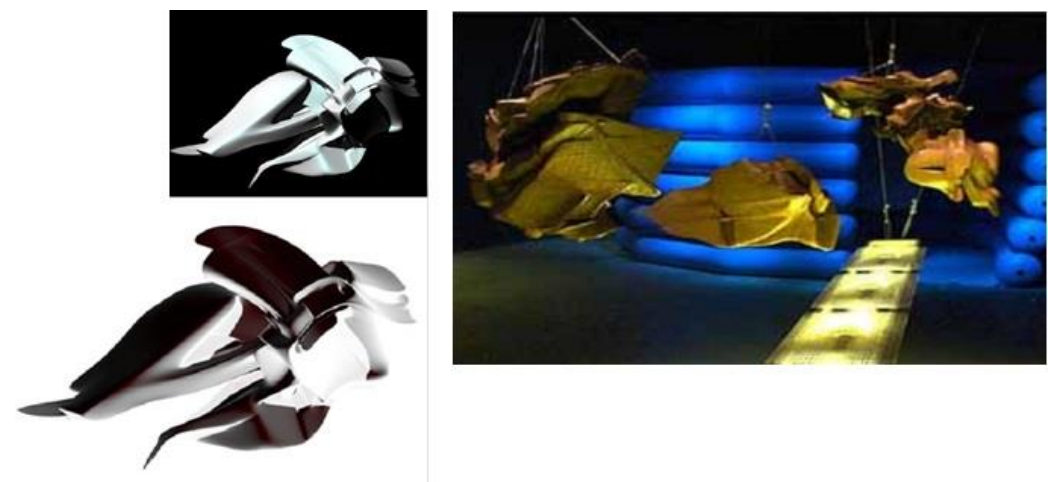

Fonte: www.centrifuge.org/marcos.

No universo dos diagramas digitais da era contemporânea, os desenhos de arquiteturas gerados por programas de animação, os blobs de Greg Lynn aspirados por avatares virtuais ou ainda os modelos parametrizados, são códigos, até então, restritos a um rol de especialistas. Manuel De Landa (2004) defende um diagrama interativo e intensivo produzido a partir da relação direta do fruidor com a materialidade e, para tanto, exemplifica seu raciocínio utilizando as estruturas tensionadas criadas por Frei Otto.

Ao modelar membranas, coberturas ou tenso-estruturas, Frei Otto usou sua criatividade enquanto arquiteto, respeitando os limites do material e manipulando-as em função de suas características plásticas. Primeiramente, experimentando a sua maleabilidade e seus esforços de tração na construção do pavilhão 
alemão para a EXPO'67 (Montreal, no Canadá) e, as posteriores aplicações, no projeto da Vila Olímpica de Munique (Alemanha, em 1972). Esse tipo de processo De Landa (2004) chama de morfogênese.

$\mathrm{O}$ arquiteto alemão trabalhou com uma infinidade de materiais: fibras naturais, algodão, aço, poliéster, fibra de carbono e o PTFE (politetrafluoretileno). Utilizou também estruturas pneumáticas, onde o ar, em combinação com uma membrana, atuava como elemento estrutural. A aplicação de forças nas estruturas sustentadas por Frei Otto são diagramas gerados a partir de uma tecnologia específica.

Na manipulação de processos de simulação ou parametrizações assistidas por computadores, onde entra a participação direta do arquiteto? Para De Landa (2004), o software apresenta performance bem precisa, mas o arquiteto, conhecendo esses programas, tem condições de criar seus próprios scripts e não se submeter diretamente a eles. Nesse jogo de forças, segundo o autor, um bom trabalho não deveria deixar vestígios do programa ou ferramenta que o originou.

Tschumi (1980, p.174) fala sobre edifícios que são construídos sem desenhos e de arquiteturas que vão além do processo de construção. Mas, como pode haver arquiteturas sem desenho? A arquitetura foi se transformando, ao longo da história, em função de complexas demandas culturais, sociais, econômicas, ambientais e filosóficas. Foram se transformando também os discursos, os enunciados, inclusive as formas de articulação com outras áreas.

Figura 10 Desenhos, esquemas e estudos de Bernard Tschumi - Centre Georges Pompidou / Paris (2014).Título da Exposição: Bernard Tschumi: Concept \& Notation.
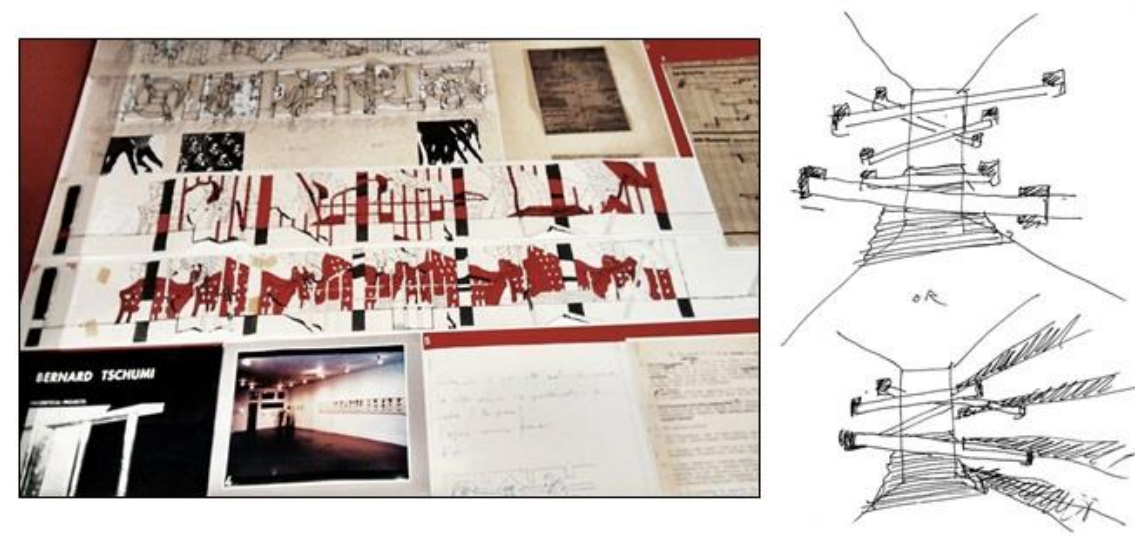

Fonte: Acervo da autora.

Para Tschumi (1980), há duas versões bem diferentes de arquiteturas produzidas no século XX, em função de novas agendas, e que se perpetuam até hoje: uma versão maximalista, voltada para questões sociais, culturais, políticas e programáticas - mega-arquiteturas. Outra, minimalista, concentrada em fatores, como estilo e tecnologia - clean architecture. Embora existam linhas dissonantes com relação à essa binaridade apontada, na produção da cidade formal, elas são dominantes.

Mesmo os defensores do Estilo Internacional acabaram reduzindo os interesses radicais do movimento moderno a maneirismos iconográficos homogeneizados. Trata-se de um processo reducionista, que se estende até os dias atuais, só que às avessas, conforme indicação a seguir (TSCHUMI, 1980, p.175):

Centrando seus ataques no Estilo Internacional, elas criam polêmicas divertidas e um jornalismo cáustico, mas trazem muita pouca coisa de novo a um contexto cultural que há muito já incorporou as mesmas alusões históricas, os mesmos signos ambíguos e a mesma sensualidade que hoje expõem.

Mesmo com tantas críticas à produção da arquitetura como Forma, é difícil escapar:

O estreitamento da arquitetura como forma de conhecimento a uma arquitetura de mero conhecimento da forma só é comparável à derrocada das generosas estratégias de pesquisa em relação às táticas operacionais dos corretores políticos (TSCHUMI, 1980, In NESBITT, 2006, p.175).

\section{A lógica do diagrama na Era da cultura midiática: tática e resistência}

Entre os velhos establishments corporativos, as trivialidades arquitetônicas e a ambiciosa intelectualidade universitária, há conflitos que correspondem, mesmo no plano teórico, a atalhas e práticas cotidianas que se travam no interior dos novos mercados, onde o diagrama é elevado ao status de vedete da cultura arquitetônica contemporânea. 
Rovenir Duarte $(2015)^{12}$ trata desse cenário como um ambiente acendido pela mídia - recheado de oportunidades e oportunistas. O diagrama ganha protagonismo midiático. O autor faz uma distinção a partir da análise de um sub-capítulo (denominando Imagem do Pensamento) do livro Diferença e Repetição (2006), de Gilles Deleuze, onde explicita dois tipos de imagem que guiam o pensamento diagramático contemporâneo: a estrutura (lógica da representação) e a rizomática (lógica da sensação). Investida como estudo de caso os trabalhos de três escritórios holandeses: Neutelings Riedijk Architecten, MVRDV e UN Studio.

O autor ainda destrincha uma série de textos e publicações sobre o tema, escritos entre os anos de 1996 e 2013. Para orientar seus estudos, utiliza dois eixos suplementares: forma sem substância (Saussure, 1945), composta pelo esquema linha + ponto = pensamento modular e estratégico; matéria sem forma (DELEUZE e GUATTARI, 2004), composta por linhas de força dinâmicas = pensamento modulado e tático.

No processo de desenho, segundo Duarte (2015), não existe uma superposição de um diagrama sobre o outro, mas repetições de estruturas reconhecíveis que, em algum momento, se desestabilizam e se diferenciam. Esses traçados são complementares e estabelecem um sistema de trocas entre si.

A manipulação de ferramentas conceituais de análise de plataformas voltadas à expressão gráfica, com características diagramáticas e com funções precisas no universo dos procedimentos de desenho na contemporaneidade, tem colaborado para o desenvolvimento de projetos arquitetônicos. A atualização proposta por Duarte (2015), embora articulada em vias de uma esfera de pensamento de particularidade pós-deleuziana, ainda se restringe ao campo formal. Ou seja, trata-se de uma significativa e competente contribuição no universo da geometria descritiva, aproximando-se de uma matemática sensível, capaz de perturbar os pressupostos geométricos euclidianos.

Figura 11 Experimentos diagramáticos: estudos realizados a partir da silhueta do abebé (espelho de Yemanjá) + transposição do protótipo para o plano cartesiano gerando diagramas - processo criativo utilizado como motor de arranque para pensar/projetar um espaço sagrado - Atelier II-FAUFBA (2008).
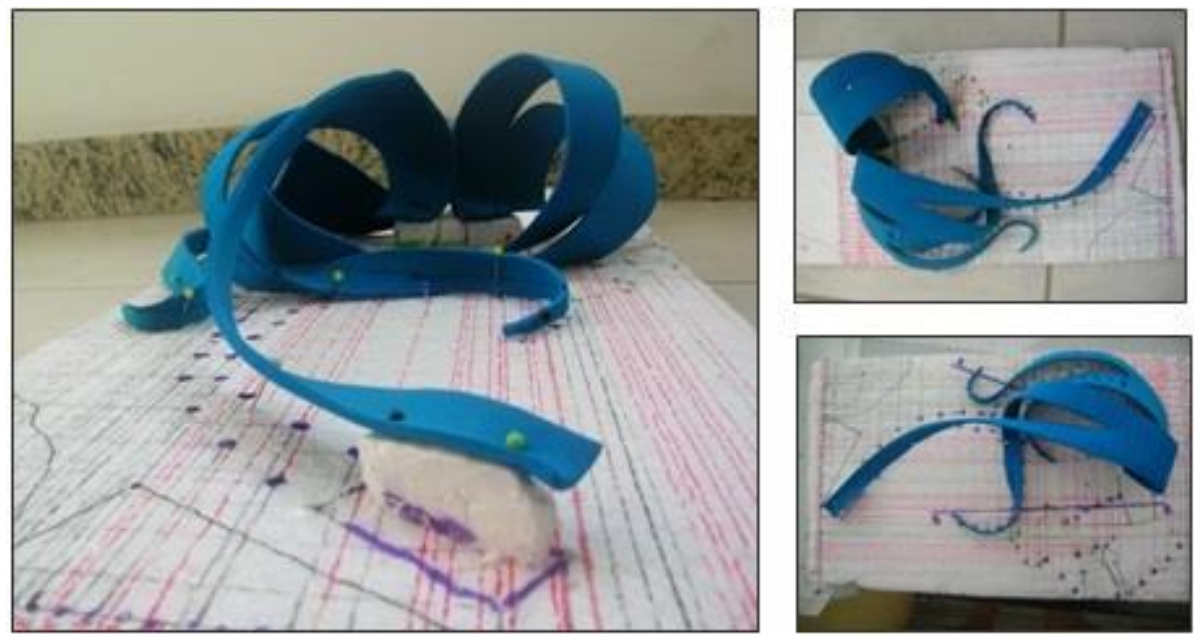

Fonte: Acervo da autora.

Arquitetura como ideograma foi desenvolvida por Victor Manuel Martinez Lopes (2009) - El Diagrama en Arquitectura, una estrategia contemporánea de proyecto - uma tática de pensamento frente aos projetos contemporâneos, porém trazendo à tona as mesmas arquiteturas e os repetidos processos operatórios presentes nos seguintes grupos de arquitetura, que são listados ad infinitum: Peter Eisenman, Alejandro Zaera-Polo, Greg Lynn, Un Studio, Rem Koolhaas, Bernard Tschumi, Steven Holl, Eduardo Arroyo, Federico Soriano, Winy Maas, Sanaa.

Muitos desses escritórios foram trabalhados, inicialmente, no desenvolvimento do mestrado ${ }^{13}$, enquanto multiplicidades de expressões estéticas, incluindo os aspectos formais. São contribuições significativas do ponto de vista de uma geometria mais sofisticada e sensível, e, está dentro de uma linha de fenômenos contemporâneos que entendem a arquitetura como obra aberta em sua própria interioridade material.

No entanto, a potência virtual do diagrama, em sua expressão incorporal, ainda precisa ser atualizada e intensamente debatida no campo da teoria e da crítica arquitetônica, ampliando as possibilidades de novos enfoques e direcionamentos capazes de problematizar uma série de deslocamentos, atravessamentos e limites do objeto frente às incertezas de seu próprio tempo. Os dispositivos de captura não estão restritos aos aspectos da exterioridade, mas se entrelaçam para além das formas arquitetônicas. São dispositivos de saberes e poderes, são enunciados de visibilidades. Essa produção transita entre estruturas sedentárias e 
distribuições nomádicas (TEYSSOT, 2012), entre a macropolítica e a micropolítica, passando de um estado a outro todo o tempo.

Ao tentar escapar das representações e provocar diferenças, resistir criativamente não corresponde a produzir arquiteturas esteticamente interessantes, desconstruídas em suas formas e revestidas dos mais altos padrões de qualidade tecnológica. Resistir assume aqui um papel de posicionamento ético, estético e político capaz de incomodar as estruturas vigentes e promover escapes às repetições formais.

Figura 12 Produção do Atelier II da FAUFBA - Processos de criação através da manipulação de modelos dinâmicos, diagramas e experimentações.
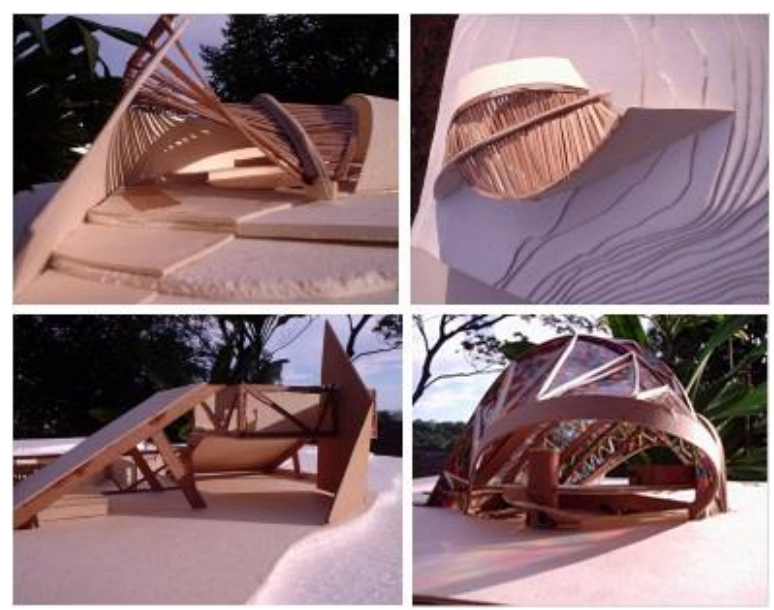

Fonte: Acervo da autora.

\section{DIAGRAMÁTICA MAQUÍNICA: INTERIORIDADE, EXTERIORIDADE, ANTERIORIDADE}

O potencial discursivo da arquitetura existe na sua própria interioridade

Peter Eisenman

O discurso próprio da arquitetura manifestada através da sua interioridade pode formular-se por si, em função de um micro regime de forças: novas estruturas de organização - comunicação, controle e transformação de padrões. Essa interioridade é similarmente examinada pelo diagrama.

Já a anterioridade, segundo Bruno Castro (2013, p.29), é a acumulação dos tropos e retóricas usadas em diferentes períodos de tempo para dar significado ao discurso arquitetônico: "com o diagrama, a interioridade formal da arquitetura pode ser aberta a questões do conceitual, de modo que as instabilidades que habitam essa interioridade sejam desvendadas e possam ser trabalhadas".

Ou seja, a anterioridade presente na história da arquitetura, na cronologia do discurso ou nos enunciados arquitetônicos, é também compreendida como agente influenciador desses processos - são forças diagramáticas. Essas forças se estendem ao universo das referências e dos acontecimentos. Vive-se sob a égide de diferentes sistemas de crenças. Alguns discursos e práticas são estudados, analisados e, consequentemente, atualizados. Outros são desconstruídos. Como criar em arquitetura um afastamento total dos conceitos dominantes e axiomas que nela habitam?

Uma arquitetura singular, ou seja, produzida na diferença, é capaz de romper com a anterioridade, com a história régia da arquitetura. Essa é a potência da crítica e é esse diagrama, em sua máxima potência expandida a outros campos (artísticos, filosóficos, científicos), que poderá transformar contextos sociais e intelectuais. Uma autonomia que não esteja sujeita à anterioridade, ou seja, uma arquitetura que não esteja sujeita à história e seus conceitos já sedimentados, mas também que não esteja sujeita à sua própria interioridade (discurso).

O diagrama deve repetir a diferença e não a igualdade, mas, também, pode ser entendido como uma tática dentro de uma estratégia crítica, a partir de seu eixo flexível, conforme Castro (2013, p.36):

O diagrama é flexível. Não possuindo a intenção de ser finito, é ele mesmo um processo, e isso pode dar-lhe a capacidade de ser tudo e simultaneamente nada. É necessário que se escrevam traços e marcas permanentes no diagrama e no projeto, pois só assim a escrita pode ser processada. Existe um limite muito tênue entre eliminar as possibilidades e sintetizá-las ou perder-se nelas. 
O diagrama, numa perspectiva de confronto, tenta situar um objeto teórico dentro de um objeto físico. É a relação entre a interioridade e o objeto teórico que é o conteúdo crítico do trabalho deslocando o funcional, o icônico e o objeto físico da arquitetura. É o objeto teórico incorporado que, num sentido, é o traço da atividade crítica; é esta atividade que se torna ideológica (idem).

Sperling (2003) analisa os procedimentos projetuais pela ótica do diagrama, através da geração de superfícies em topologia. Ele trabalha forma e estrutura através da modelagem algébrica; a continuidade espacial, através de superfícies e teoria dos grafos; a produção de arquitetura virtual por dimensões espaciais; a arquitetura mutável e efêmera pelo dispositivo do evento. São meta-arquiteturas, ou seja, simultaneamente entendidas como processo e produto.

Figura 13 Conexão de diagramas: zonas de função e exterioridade - a rede urbana e a nova paisagem determinam os traços do processo contaminando os estudos volumétricos e estruturais da Biblioteca L'inuei.
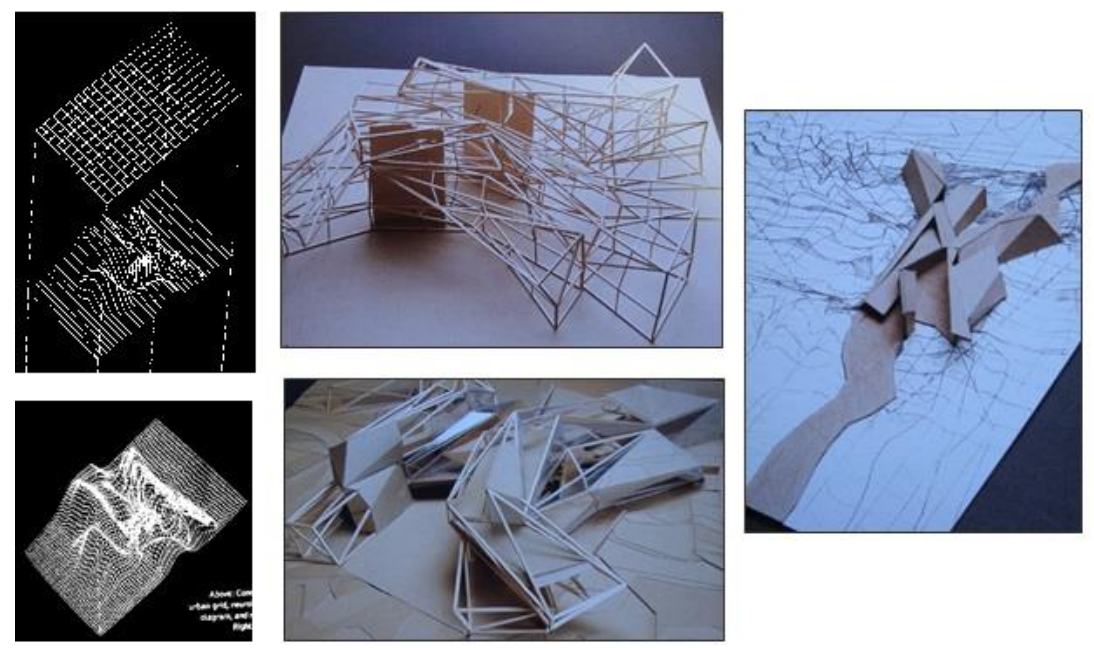

Fonte: TRACING EISENMAN (2007).

O diagrama enquanto processo é desenvolvido em três níveis (idem, p.146): trans-diagramas (entre diagramas internos e externos) / intra-diagramas (inerentes a elementos formadores) / inter-diagramas (encadeamento lógico e relações de similaridade e contiguidade).

Conforme Somol (2001), o diagrama funciona como intermediário no processo de geração do espaço-tempo real. Ele é simultaneamente forma e matéria, o visível e o articulável. As condições de presentidade como a condição do tempo arquitetônico, ou a arquitetura como condição do ato, estão presentes no diagrama visto como um signo indicial. O signo indicial, que sempre implica uma condição de ausência, sugere uma ideia de tempo no diagrama.

O mundo da representação é uma manifestação das exterioridades. Mas aquilo que dobra e que busca emancipação desse controle social existente é a ética da interioridade do diagrama. E é essa potência éticaestética emancipadora (e não modelo ou paradigma) que se quer perseguir.

Otavio Lacombe (2006) compreende os diagramas digitais enquanto diagramações maquínicas, estreitadas pela lógica icônica herdada da semiótica. A imagem e as similaridades entre desenho e diagrama são aproximadas pela analogia. A partir da segunda metade do século XX houve uma significante mudança no modo de pensar a arquitetura e, essa transformação, se revelou pelo procedimento fundamental de projetar pela operacionalização direta do desenho para o diagrama. O diagrama, no entanto, é mais aberto que 0 desenho, pois indica inúmeras possibilidades. E se o diagrama assumiu o lugar do desenho como pensamento da arquitetura, como realizar tal pensamento e processá-lo como linguagem?

Lacombe (idem) busca em Charles Peirce o entendimento do diagrama como um signo relacional. Se, em Guattari, o diagrama é uma função do algoritmo, em Foucault, o panoptismo e, em Deleuze, o diagrama informal é elevado à condição de máquina abstrata, Lacombe (ibidem, p.133) conclui: "nem toda máquina é ótica, mas no caso da arquitetura, pode fazer ver, traz algo à luz, faz surgir visibilidades". O diagrama, sendo uma exposição das relações de força que constituem o poder, vai desembocar na organização do poder sobre a vida: o biopoder (terminologia criada por Foucault) e toda uma sistemática de dispositivos disciplinares estrategicamente rebatida sobre a urbanística e suas cartografias. 
Figura 14 Sistema panóptico proposto por Jeremy Bentham (século XVII). A microfísica do poder: vigília, disciplina e punição. O diagrama, enquanto relações de forças que constituem o biopoder: sujeição e normatização.
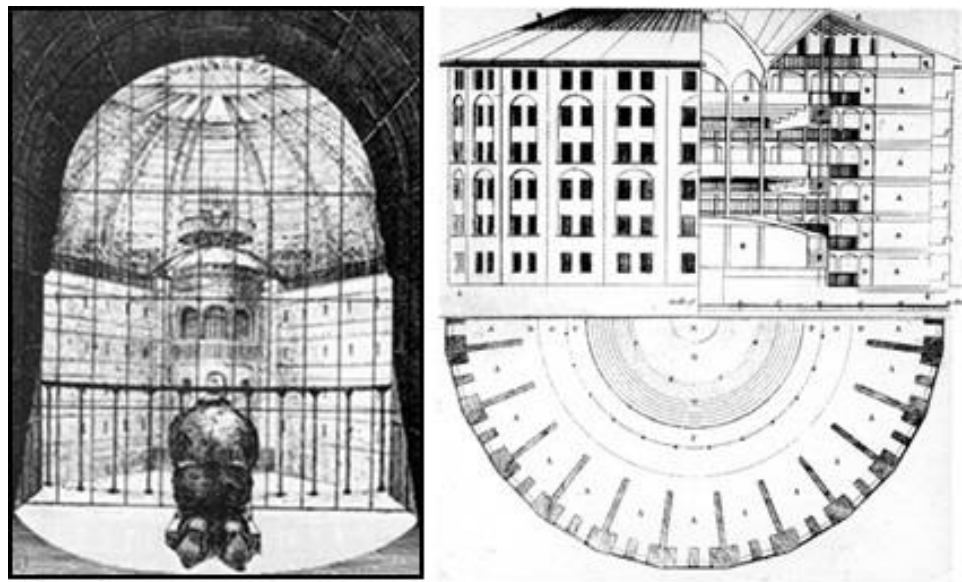

Fonte: Mark Garcia (2010).

No pensamento diagramático ou maquínico, as matérias e funções que constituem mutações não se rendem a um diagrama de forças mecânicas, submetidos à física clássica e moderna (geometrização de forças), mas vão ao encontro do diagrama como pulsação de forças - fluxos, intensidades e desejos. Todo diagrama está em processo, em devir.

\section{CONSIDERAÇÕES TRANSITÓRIAS}

Os diagramas podem ser encontrados em vários lugares, nas pequenas engrenagens às produções mais ambiciosas, na vida cotidiana das ruas ao mundo da cultura digital, nos processamentos em rede às plataformas de informação, nas contrações do espaço-tempo à cronopolítica dos intermináveis desdobramentos. Na era da comunicação digital e do capitalismo informacional, tudo se espetaculariza!

(...) à tecnologia, com foco na nano-tecnologia, que permite que nos relacionemos com as nossas construções de um modo que somente os pós-modernistas haviam imaginado. Estas relações, estes conflitos (proveitosos ou não) podem refletir-se no modo como construímos, sendo a construção, invariavelmente, o reflexo desses conflitos. O diagrama pode ser uma vez mais o mecanismo que reflete a vontade de reunir todas essas preocupações, o mecanismo que permite a análise e a operatividade. Pois, num mundo onde as manifestações formais são cada vez mais abrangentes, o diagrama pode ser o instrumento capaz de olhar para além dessas "semiotizações" (CASTRO, 2013, p.22).

Deleuze (2007a, p.19) aponta essa dificuldade: como ir além das "semiotizações"? Como escapar dos clichês e das superfícies previamente revestidas? Ele faz um paralelo com a arte pictural: foi necessário um esforço considerável e um trabalho extraordinário, engendrado pela pintura abstrata, para arrancar a arte moderna da figuração. A pintura de Francis Bacon aparece nesse percurso como uma potente aliada capaz de engendrar uma singularidade de forças invisíveis, maquinação que Deleuze estende à experiência do abstracionismo.

Nas pinturas de Francis Bacon, há um esforço para eliminar todo espectador, e, com isso, todo espetáculo: "na verdade, o único espetáculo é o da espera ou do esforço produzidos apenas quando não há mais espectadores" (DELEUZE, 2007a, p.21) ${ }^{14}$.

Figura $15 \mathrm{O}$ ato de pintar em Francis Bacon. Acaso, variações, formas de indeterminação, esboços e traços de sensação.
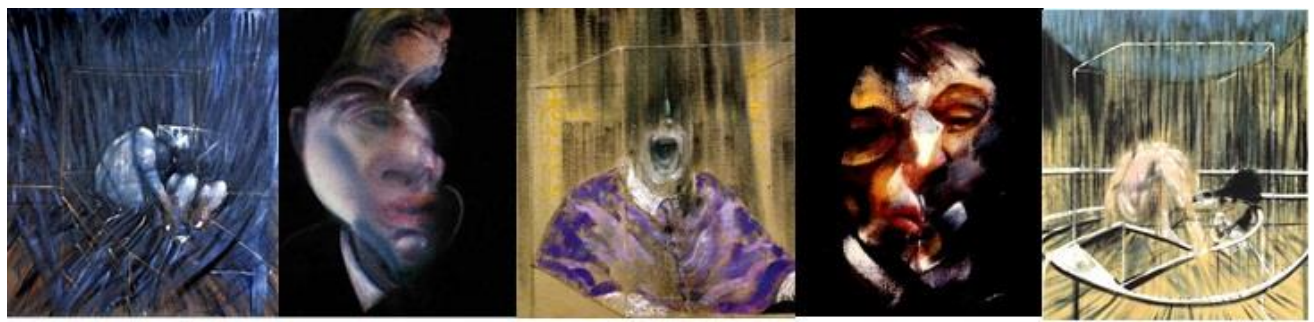

Fonte: www.enchgallery.com / www.artenet.com / www.thismoment.pwp.blueyonder.co.uk / Russell (2004). 
Há um contraste entre dois regimes: o da invisibilidade imanente e o da visibilidade total. Segundo Pelbart (1993, p.52), no regime da visibilidade total, do esbanjamento infinito de imagens, dessa promiscuidade tátil com elas, o que teria acontecido ao nosso invisível, supondo-se que ele exista? "Se colocamos por um instante entre parênteses essa tipologia simplória do invisível como imanente, transcendente, subjetivo ou imagético, do que se trata para nós?" É uma questão a ser pensada.

Pode-se observar a propagação de uma política de arranha-céus cada vez mais em voga no skyline das cidades e que obedece a algumas lógicas: a espetacularização dos centros urbanos, as arquiteturas que servem a diversos poderes e mídias, a inserção de grifes globalizadas em estreita conexão com a revolução tecnológica e com a inovação digital presente nos sistemas das grandes corporações.

A arquitetura contemporânea quer ser vista. Os arquitetos divulgam suas obras e seus processos em todos os canais possíveis de comunicação, sejam analógicos ou digitais. Há uma superexposição, um panóptico digital que a tudo captura, potencializa a imagem e a veicula. Potência midiática editada. Profusão de hiperrealidade, manipulação, simulação e photoshop!

Os tempos são midiáticos, com certeza, cheios de espelhos digitais. As fachadas tem rostos delineados e iluminados. As paisagens e suas arquiteturas são mediadas, demarcadas por traçados e cartografias que ignoram as linhas do devir. A mídia ignora o tempo da espera e fixa o acontecimento. Deleuze (1992, p.198) explica: "primeiro, porque ela mostra com frequência o começo ou o fim, ao passo que um acontecimento, mesmo breve, mesmo instantâneo, se prolonga. Segundo, eles querem o espetacular, enquanto 0 acontecimento é inseparável de tempos mortos".

A arte tem o poder de captar o acontecimento, de forma ativa e criativa, dobrando em turbilhões o improviso e o ordinário, na espera ou na lentidão - é possível fabricar outros gestos. As linhas não são regulares e os diagramas ainda têm algum território de ação nas beiradas desse fetichismo mercantil, no qual se transformou os terrenos onde estão sendo fixadas as sedentárias estruturas arquitetônicas.

O desenho é também um instrumento de controle e poder. Rovenir Duarte (2012) sinaliza que o uso do diagrama oferece a sensação de certa autonomia, como se liberasse o arquiteto de uma teia de firmeza e solidez, para lançá-lo à bases mais fluidas e abertas, porém, pode ser uma falsa impressão. É muito fácil cair em armadilhas de abordagens genéricas e unitárias - imaginar que uma arquitetura cujas formas estejam em movimento ou "desconstruídas" não corresponde ao seu caráter libertário.

O diagrama vai muito além de uma exposição superficial e hoje em dia encontra-se também capturado na utilização de alguns arquitetos contemporâneos que se apropriaram desse discurso (enunciado) para justificar suas produções e para utilizá-los como marketing de seus próprios processos projetuais.

Entre diagramas, potências diagramáticas, ocupações, disputas de território, criações e resistências, a produção de micro-rupturas ou fluxos táticos, imbricadas nas artes do fazer (DE CERTEAU, 1998), podem funcionar como dispositivos para encontrar as brechas de uma ação política eficaz. Os receituários não dão mais conta das situações e representações hegemônicas, afinal de contas, não há neutralidade nos processos inventivos, mas redes capilares de poderes e saberes que se contaminam em zonas de vizinhança nem sempre precisas. Para além do primado da geometria, já está explodindo por aí o diagrama nômade, o diagrama da multidão, o diagrama do anonimato - em constante devir e em permanente transformação.

\section{Concluindo}

Muitas arquiteturas produzidas de maneira altamente sofisticada, em seus processos experimentais, rompem com a lógica cartesiana através de uma geometria dinâmica e sedutora em seus aspectos formais: artefatos espetaculares! Outras, ainda submetidas a um traçado funcionalista e repetitivo, servem para a disseminação de estruturas estáticas a serviço do capital: especulação imobiliária! Ambas, a serviço das corporações travestidas de desenvolvimentismo econômico e cultural - são, portanto, conservadoras!

Qual é o problema, então, no trabalho de arquitetos que capturaram alguns desses conceitos e dispositivos (desconstrução, diagrama, entre outros) e tentaram rebater na produção de suas arquiteturas? A desconstrução não é um sistema ou um método, mas uma estratégia para reinventar o mundo, propor mudança de hábitos e formas de pensar. Ao tentar liberar a arquitetura do seu valor de presença, no plano da ausência e do abandono da significação, defendidos por Derrida, Eisenman percebeu que era impossível desvencilhar um projeto de sua condição metafísica. Para ele, a produção material da arquitetura precisa se relacionar com algum dado de realidade, portanto, articulá-la com o termo "desconstrução" soava demasiadamente metafórico e literal (EISENMAN, 1988), até porque, a obra precisa ser implantada em algum território e isso significa vinculá-la a um dos principais axiomas do capitalismo - a propriedade privada. 
A relação do espaço arquitetônico entre o "visitante" e a experiência do lugar não estão apartados de condicionantes ligados aos processos participativos e colaborativos, por exemplo, questão que grande parte dos arquitetos que transitam entre os poderes hegemônicos e grifes internacionais, refutam até hoje. Esses procedimentos, passando pela diagramática maquínica, por engrenagens abstracionistas, plataformas digitais ou sofisticados planos geométricos, embora sejam potentes nos aspectos formais e conceituais pontuados ao longo do texto e suscitem reflexões estimulantes para o universo da produção e do ensino da arquitetura, ainda assim, são exercidos para as grandes corporações e capitais especulativos que produzem mares de segregação, exclusão e diferença social nos centros urbanos. Além do mais, desconsideram a tríade saber/poder/subjetividade, se abrigam de composições formalistas à guisa de ícones sedutores e desvinculam a cooperação do usuário ${ }^{15}$ em seus processos de elaboração.

Montaner (2017, p.37) faz coro ao indagar que o diagrama enquanto vontade de ação imbricado puramente como dispositivo instrumental, pode ser uma armadilha, caso não incorpore as complexidades de uma retroalimentação contínua das abstrações com a energia, a vitalidade e as experiências da própria vida. É nesse sentido que a transmutação diagramática, segundo o autor, deve estar intimamente conectada com os instrumentos de ação social para projetar espaços de relacionamento interpessoal.

Entende-se que algumas experimentações arquitetônicas tentaram engendrar algum tipo de crítica ao pósmodernismo, à velha sociedade industrial e às limitações da geometria euclidiana. É possível visualizar nos corpos dos edifícios projetados, bem como nos desenhos geradores, fissuras, torções, desequilíbrios, fragmentações, descontinuidades, instabilidades. O desenho e suas interfaces com a educação e a cultura contemporânea, por exemplo, são campos férteis de diálogos que precisam ser reinventados cotidianamente.

Nesse ambiente efêmero e líquido, o processo, o modo de fazer, também se torna espetáculo e é cooptado pela hegemonia das lógicas de mercado. São poucos os campos de uma diagramática de escape que dialogue com um outro paradigma ético e estético capaz de transformar as estruturas da condição contemporânea em que a arte, a arquitetura e o pensamento possam ser instrumentos de mobilidade não estratificada, conforme alerta Félix Guattari (1992).

Arquiteturas e seus territórios são transformados e modificados em função dos mais variados motivos: políticos, sociais, culturais, geográficos, econômicos, étnicos. Compreender as lógicas de poderes, incorporando conflitos e todo tipo de negociação nos procedimentos do saber/fazer práticas nesse campo heterogêneo é um dos desafios dos arquitetos e urbanistas. Nesse contexto, um diagrama de forças deflagra a perda de hegemonia de um saber e de uma forma de pensar que, todavia, continua coexistindo com novas construções e criações em processo, cada vez mais abertas e desterritorializadas.

\section{REFERÊNCIAS}

CASTRO, Bruno Daniel S. A. O diagrama como mecanismo de confronto. Universidade do Minho, Escola de Arquitectura, 2013.

DE CERTEAU, Michel. A invenção do cotidiano - artes de fazer. Petrópolis: Vozes, 1998.

DE LANDA, Manuel. Deleuze and the use of genetic algorithm in architecture. Art and Technology Lecture Series, 2004. Disponível em https://www.youtube.com/watch?v=50-d_J0hKz0

DELEUZE, Gilles. Conversações. Rio de Janeiro: Ed. 34, 1992.

DELEUZE, Gilles. Diferença e repetição. Rio de Janeiro: Graal, 1988, 1a edição, 2a edição, 2006.

DELEUZE, Gilles. Foucault. São Paulo: Brasiliense, 2005.

DELEUZE, Gilles. Francis Bacon: lógica da sensação. Rio de Janeiro: Jorge Zahar Ed., 2007a.

DUARTE, Rovenir B. El diagrama arquitectónico despues de Deleuze: estudio de casos holandeses. Tesi doctoral, Programa de doctorat en Comunicació Visual en Arquitectura i Disseny, UPC, 2015.

DUARTE, Rovenir. Radicalizando por diagramas. São Paulo: Portal Vitruvius, abril de 2012. http://www.vitruvius.com.br/revistas/read/arquitextos/12.143/4275

DELEUZE, Gilles; GUATTARI, Félix. Mil platôs: capitalismo e esquizofrenia. São Paulo: Ed. 34, Volume 1, 1995.

DELEUZE, Gilles; GUATTARI, Félix. Mil platôs: capitalismo e esquizofrenia. São Paulo: Ed. 34, Volume 5, 1997.

EISENMAN ARCHITECTS. Codex. The City of Culture of Galicia. New York, The Monacelli Press, 2005a.

EISENMAN, Peter. Contropiede. A cura di Silvio Cassarà. Modena: Skira, 2005b.

EISENMAN. Peter. Diagram diaries. London: Thames \& Hudson, 2001. 
EISENMAN. Peter (1988). Em busca de uma arquitetura pós-hegeliana. Entrevista concedida a Fuensanta Nieto e Enrique Sobejano publicada originalmente em Arquitectura, Madrid: n.124. fev/1988. In Revista Projeto, São Paulo: n.118, jan/fev de 1989, p.117-120.

EISENMAN, Peter. Giuseppe Terragni: Transformations, Decompositions, Critiques. The Monacelli Press, 2003.

FOUCAULT, Michel. Surveiller et punir - naissance de la prison. Paris: Gallimard, 1975.

GARCIA, Mark. The diagrams of architecture. London: John Wiley \& Sons Ltd, 2010.

GUATTARI, Félix. Caosmose: um novo paradigma estético. São Paulo: Editora 34, 1992.

LAPOUJADE, David. O pensamento enquanto prática imanente decorrente da experiência vivida, segundo a singularidade deleuziana. Palestra. São Paulo: 2013. Disponível no site acessado em 06/04/2017: http://vimeo.com/77238678

LACOMBE, Octavio. Diagramas digitais: pensamento e gênese da arquitetura mediada por tecnologias numéricas. Tese de Doutorado, São Paulo: FAUUSP, 2006.

MONTANER, Josep M. Do diagrama às experiências, rumo a uma arquitetura de ação. São Paulo : Gustavo Gili, 2017.

PELBART, Peter Pál. A nau do tempo-rei: sete ensaios sobre o tempo da loucura: Rio de Janeiro: Imago Ed., 1993.

RUSSELL, John. Francis Bacon. Paris: Thames \& Hudson, 2004.

SILVA, Ariadne M. Entre a pintura de Francis Bacon e a arquitetura de Peter Eisenman - a lógica do diagrama. In: SOULAGES, François; Olivieri, Alberto; SILVA, Ariadne M.; BIRIBA; Ricardo (org). O sensível contemporâneo. Salvador: EDUFBA, 2010, p.61-71.

SILVA, Ariadne M. O conceito de diagrama na interface da arquitetura: a emergência da abordagem diagramática na produção contemporânea. Tese de Doutorado. Salvador: PPG-AU/FAUFBA, 2015.

SOMOL, Robert. Dummy text, or the diagammatic basis of contemporary Architecture. In: EISENMAN, Peter. Diagram Diaries. London: Thames \& Hudson, 2001, p.6-25.

SPERLING, David M. Arquiteturas contínuas e topologia: similaridades em processo. Dissertação de Mestrado, Escola de Engenharia de São Carlos, Universidade de São Paulo, 2003.

SPERLING, David M. Diagramas e eventos: o espaço e a forma em mutação. Cuba: Congreso SIGraDi - CCIA -, 2008a.

TEYSSOT, Georges. O diagrama como máquina abstrata. Vírus: São Carlos, n.7, junho de 2012.

TRACING EISENMAN. Peter Eisenmam complete works. Edited by Cynthia Davidson. London: Thames \& Hudson, 2007.

TSCHUMI, Bernard (1980). Arquitetura e limites II. In: NESBITT, Kate (org). Uma nova agenda para a arquitetura: antologia teórica (1965-1995). São Paulo: Cosac Naify, 2006, p. 179-182.

VIDLER, Anthony. Architecture's expanded field. In: SYKES, Krista. Constructing a New Agenda: Architectural Theory 1993-2009. Nova York: Princeton Architectural Press, 2010.

VIDLER, Anthony. Diagrams of Diagrams: Architectural Abstraction and Modern Representation. Berkeley: University of California, 2000.

\section{NOTAS}

1 Um diagrama é uma heterogênese, pois nele se entrelaçam diagramas conceituais (filosóficos), diagramas funcionais (científicos) e diagramas perceptivos e afetivos nas artes, pois, os diagramas arquitetônicos da arte são atravessados por diagramas conceituais da filosofia e diagramas funcionais das ciências, embora tais diagramas não a determinem, pois a arte tem a sua especificidade na heterogênese do diagrama. Sobre as principais atualizações discursivas e experiências diagramáticas, Cf. Silva, Ariadne Moraes (2015). O conceito de diagrama na interface da arquitetura - a emergência da abordagem diagramática na produção contemporânea Capítulo I: Motor de Arranque.

2 Cf. El Croquis 77, $\mathrm{n}^{0} .1$ - 1996. Diagram Architecture. Para verificar demais imagens, gráficos, esboços e diagramas relacionados neste artigo, acessar o link: http://www.ppgau.ufba.br/node/1712

${ }^{3}$ Cf. Duarte (2012). Radicalizando por diagramas - por favor, devagar no mar agitado das novidades.

${ }^{4}$ Até então, não havia nenhuma referência a Deleuze nos escritos ou processos de arquitetos ou urbanistas que utilizavam o diagrama como meio de pensar e produzir arquiteturas. Hoje, há uma série de menções ao filósofo e apropriações as mais diversas: "arquitetura rizomática", "arquitetura nômade", entre outras. 
${ }^{5}$ Os dispositivos presentes na pintura de Bacon permitiram que Deleuze explorasse ao máximo essas concepções, operando, dentro de uma rede conceitual, conexões cada vez mais ampliadas que possibilitam pensar transformações potencializadas, o que o filósofo francês David Lapoujade (2013) chama de "movimentos aberrantes" e suas lógicas irracionais. A pintura de Bacon e a filosofia de Deleuze são práticas de transgressão.

${ }^{6}$ Cf. Eisenman (2003). Giuseppe Terragni: Transformations, Decompositions, Critiques.

${ }^{7}$ Os planitas, uma herança suprematista criada pelo artista russo Kasimir Malevich (1878-1935), são desenhos que transitam entre a bidimensionalidade e a tridimensionalidade, entre a pintura e a arquitetura ao mesmo tempo.

${ }^{8}$ Método de criação através da manipulação de modelos dinâmicos e da interface das artes plásticas enquanto processo para geração de formas.

${ }^{9}$ Aula do filósofo Gilles Deleuze ministrada na Université Paris VIII Vincennes - Saint-Denis, na França. Cf. https://www.youtube.com/watch?v=4DL7esiiECs

${ }^{10} \mathrm{O}$ campo de incidência do poder já não é prioritariamente o controle dos corpos no espaço, com seus dispositivos de exclusão ou reclusão, mas o do controle do tempo (PELBART, 1993, p.38). O poder é uma rede produtiva que se estabelece na sociedade através de mecanismos cuja vigência é a história! Portanto, o poder sendo um exercício e o saber um regulamento, a "história" e seus sistemas de linguagem são marcações temporais do poder.

11 1. Noção de paisagem, que vem sido reinterpretada através de modelos digitais de novas cidades e planos a partir de fluxos + inserção de formas topológicas em menores escalas, processo utilizado por Ben van Berkel e Caroline Bos do UNStudio, Winy Maas do MVRDV e Lars Spuybroek do NOX. 2. Analogias biológicas, processos que têm aproximado a arquitetura dos universos do design e da indústria de animação, tendo como seus principais representantes Marcos Novak, Greg Lynn, Cristina Díaz Moreno e Efrén Garcia Grinda, vertente iniciada por Reyner Banham e os Metabolistas na década de 1960. 3. Programa, esse tipo de "modelo" foi e é altamente disseminado como eixo regulador da arquitetura funcionalista e tem hoje, em Rem Koolhaas, seu principal expoente; o arquiteto holandês colocou em pauta o fenômeno da cultura e da congestão ao pensar projetos na escala metropolitana e nas redes globais. 4. Forma arquitetônica ou recursos formais, são explorações que desnudam a linguagem arquitetônica como um exercício iniciado desde as análises do tipo (Andrea Palladio, Terragni, Argan) e das correntes modernas (e uma série de "genitores"), transformadas pelas vanguardas artísticas do início do século XX - Peter Eisenman transitou bastante nesse campo. Essas pontuações foram sugeridas resumidamente por Vidler (2010), para antecipar um pouco em que território emaranhado se meteu 0 nosso querido diagrama.

12 C.f. Tese de doutorado defendida em 20/01/2015, na Universidad Politécnica de Cataluña UPC Barcelona Tech, intitulada El diagrama arquitectónico despues de Deleuze: estudio de casos holandeses.

${ }^{13}$ Dissertação de Mestrado intitulada "Entre processos e perceptos - arquiteturas contemporâneas: multiplicidade e heterogeneidade de expressões estéticas", apresentada ao Programa de Pós-Graduação em Arquitetura e Urbanismo da Universidade Federal da Bahia (2009).

${ }^{14}$ C.f. Deleuze (2007a). Francis Bacon: a lógica da sensação. Ao longo de sua vida como filósofo, Deleuze buscou afirmar o pensamento da diferença em contraposição ao pensamento subordinado à representação. Por exemplo, um pensamento que necessita de uma imagem para representar, privilegia a identidade; Deleuze queria escapar dessa submissão, ao se aliar a pensadores e artistas que se abrigavam da diferença (a exemplo de Espinosa, Nietzsche e Bergson, no campo da filosofia, mas também Kafka, Zola, Beckett e Bacon, citando alguns autores não filosóficos) para criar conceitos nos quais fosse possível desenvolver um pensamento apartado de um suporte representacional (imagem versus texto). Na obra de Bacon, ele encontra uma pintura que escapa ao figurativo (representação) e não se atêm a um modelo, mas vai ao encontro de uma abstração ou potencializa a própria figura como expressão (figural).

15 Ao enfatizar suas investigações a partir da autonomia da arquitetura, Eisenman foca a formalidade de sua interioridade e desconsidera fatores externos a ela, inclusive a participação colaborativa dos usuários, os considerando como leitores e não coadjuvantes nos processos de concepção.

NOTA DO EDITOR (*) O conteúdo do artigo e as imagens nele publicadas são de responsabilidade do(s) autor(es). 